Duška Jović1, Darija Knežević, Milan Skrobić,

\section{Attitudes and Opinions of Health Care Students of Medical Faculty in Banja Luka about Study Program and Nursing as a Profession}

\begin{abstract}
Introduction: The level of education quality of medical health care graduates (Bachelors of Health care and Nursing) depends on curriculum quality. Knowing what motivates students to enroll medical health care studies and development of professional and academic career are of great importance for education as well as the practice.
\end{abstract}

Aim of the study: To see if there is a difference in attitudes and opinions between 1st year students and 4th year students about health care study program and nursing as a profession, students motivations for enrolling the program and their expectations about possibilities to develop personally, professionally and scientifically after graduating.

Patients and Methods: 55 Health care students of Medical Faculty University of Banja Luka (1st year 37 and 2nd year 18 students) were a sample. Research was conducted by using anonymous, original questionnaire which was written for the needs of this research. SPSS (Statistical Product and Service Solutions) version 20. was used for data processing, and Windows, operating system, for data analysis.

Results: Conducted research shows that material component, with possibility of finding better job and willingness to care for other people are major criteria which motivate students to choose nursing study. Health care students of both generations graded study program with 3,22 $\pm 0,76$, and there was statistically significant difference $(p<0.001)$ concerning access to literature and companion paper. Both generations of students have positive attitudes about nursing as a profession. Majority of the students (1st year $=77,8 \%$; 4 th year $=75,7 \%$ ) showed interest for further academic development after graduating the study of Health care. A large number of students chose going abroad (1st year 67,6\% ; 4th year 77,8\%), whereas minority of the students have desire to stay in their own country after graduating.

Conclusion: Motives for enrolling the study of Health care in this country and in other countries have no significant differences, and the most frequently cited reasons are possibility of finding better job, and desire to help other people. Academic study program of Health care should be extremely high-quality and alluring enough to draw attention of young students as well as the older students.

Key words: nursing, students' attitudes, enrolling motives, expectations
Amela Matavulj ${ }^{1}$ and Jasminka Vučković ${ }^{2}$

${ }^{1}$ Medical Faculty, University of Banja Luka

2 Ministry of Health and Social Security of the Republic of Srpska

\section{Contact:}

Duška Jović

Medical Faculty, University of Banja Luka, Health Care Study Program Save Mrkalja 14, Banja Luka, Republika Srpska

Tel.o51 234 -100; 065 421-977 e-mail: jovicduska@yahoo.com 


\section{Introduction}

Medical Faculty University of Banja Luka founded Health care study program in school year 2007/08. Title which is gained after finishing this study program is Bachelor of Health care and Nursing.

Recommendations of American Institute for medicine point that it is necessary to enable education for nurses who are not college-educated and it is expected that $80 \%$ of nurses will be college-educated by $2020 .{ }^{1}$ There are strong recommendations of international professional boards, organizations and state regulations that nurse education should be raised to university level..$^{1-4}$

Level of education quality of medical health care graduates depends on curriculum quality. Integrative study conducted by literature review shows quality of nursing curricula which were published during a period of forty years. This study shows that only eight out of 27 studies include students' opinions about curriculum. The results point that there are significant limitations which are related to quality level improvements of curricula. ${ }^{5}$ Education programs for nurses must be based on constant monitoring and self-evaluation of work and cognitive research. ${ }^{2}$ Health care students should be theoretically and practically qualified for performing health care procedures within their competence. ${ }^{6}$

When we talk about motives for enrolling health care studies in other countries, there are many reasons, and the most common motives are willingness to help others, possibility of finding better job, and possibility for further career development and financial motivation..$^{7-9}$

In our country there is not knowledge about students motives for enrolling health care studies as well as their expectations for their personal, professional and scientific development of nurses after graduating.

\section{Aim of the study}

To see if there is a difference in attitudes and opinions between 1st year students and 4th year students about health care study program and nursing as a profession, students motivations for enrolling the program and their expectations about possibilities to develop personally, professionally and scientifically after graduating.

\section{Patients and Methods}

All respondents were 1st year and 4th year students of Health care students of Medical Faculty University of Banja Luka. 55 students were involved in the research (1st year 37 (67\%) and 4th year 18 (33\%) students). Research was conducted in December 2014, during regular classes.

For the needs of this research, original questionnarie was constructed on the basis of important literature review, and research was conducted by anonimus questionnarie which was given to students.

Questionnaire was made of 25 questions, divided into three parts:

I part - included questions about respondents' sociodemographic characteristics (7 questions)

II part - included questions about attitudes and opinions of Health care students (8 questions)

III part - - included questions about attitudes and opinions of students about nursing as a profession (10 questions)

Offered answers were represented by Likert scale in the range of 1-5 (1 - I disagree completely, 5 - I agree completely). Respondents had to answer YES or NO to other claims. Questionnaries were personally handed by researches to the repondents with detailed explanation of research aim and methods how to fill the questionnarie. Permission to conduct this research was granted by the competent institution.

\section{Results}

There are 37 respondents out of 59 students (63\%), generation of 2014/15 school year, and there are 18 respondents out of 25 students (72\%), generation of 2010/11 school year. By gender, there are more females: F $=46(83,6 \%), M=9$ (16,4\%).

Generation of 2010/11 school year has the biggest number of respondents who are within the age group of 23 to 27 (44\%), and the smallest number of respondents who are within the age group of 33 to 37 (6\%), and generation of 2014/15 school year has the biggest number of respondents who are within the age group 18 to 22 (97\%), only $3 \%$ those who are within the age group of 23 to $27, \mathrm{t}(53)$ $=6.23, \mathrm{p}=0.000$. The largest number of respondents finished medical high school -50, $9 \%$, and than those who finished high-school (gymnasium) 25, $5 \%$, and 23, 6\% of students who finished other high schools. Of total number of respondents 56, 4\% finished high school in 2014 (2011,9 $\pm 3,3$ ). Among the respondents there is a majority of those who are unemployed (96, 4\%).

Respondents of Health care study program of Medical Faculty University of Banja Luka agree the most with the claim that they will find a better job after graduating Health care studies (I year 81,1\%; IV year, 66,6\%) and with the willingness to help other (1st year, $78,4 \%$; 4 th year, $72,2 \%$ ). Students do not agree with the claim of inability to enroll what they wanted at first (1st year, 18,9\% ; 4th year, 16,7\%). 
Table 1. Students' attitudes and opinions about health care study program

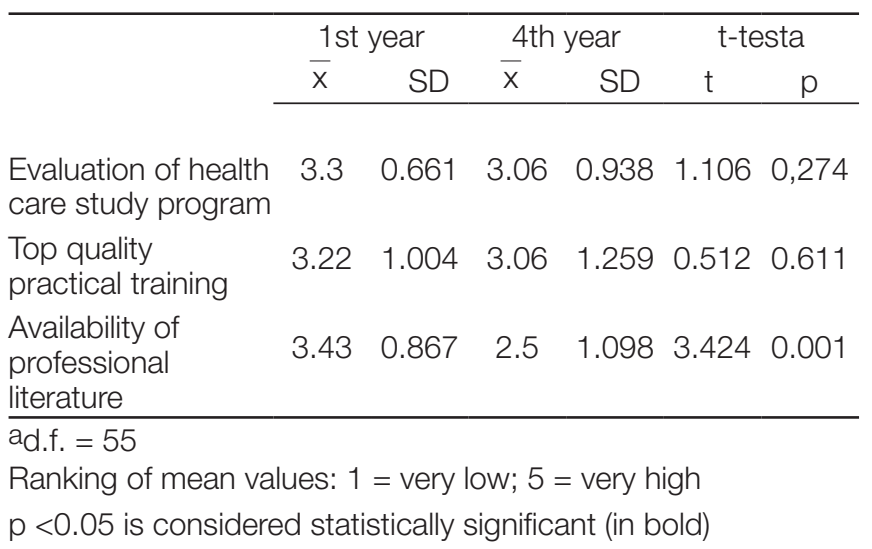

Results of the attitudes and opinions of health care students' research are compared by the T-test of the independent samples (Table 1.). There was not statistically significant difference in evaluating health care study program and top quality practical training between 1 st year students and 4 th year students. There is statistically signicicant difference regarding availability of professional literature among 1st year students $(3.43 \pm 0.87)$ and 4 th year students $(2.5$ $\pm 1.19)$; $\mathrm{t}(55)=3.42, \mathrm{p}=0.001$ (mutual). Students had professional and scientific advancement in their expertise (Table 2.).

Table 2. Students' attitudes and opinions about professional and scientific improvement of nurses

\begin{tabular}{|c|c|c|c|c|c|c|}
\hline \multirow[b]{3}{*}{$\begin{array}{l}\text { Competences } \\
\text { acquired in the study } \\
\text { of health care are } \\
\text { used at new work and } \\
\text { for the purporse of } \\
\text { promotion at work }\end{array}$} & \multicolumn{2}{|c|}{ 1st year } & \multicolumn{2}{|c|}{ 4th year } & \multicolumn{2}{|c|}{ t-testa } \\
\hline & $\bar{x}$ & SD & $\bar{x}$ & SD & $\mathrm{t}$ & $p$ \\
\hline & 2.38 & 0.721 & 2.50 & 0.857 & 0.552 & 0.584 \\
\hline $\begin{array}{l}\text { Bachelor of science in } \\
\text { nursing contributes to } \\
\text { the professional and } \\
\text { scientific progress of } \\
\text { nurses }\end{array}$ & 1.86 & 0.585 & 2.00 & 0.594 & 0.800 & 0.427 \\
\hline $\begin{array}{l}\text { Nurses or medical } \\
\text { technicians can reach } \\
\text { the highest level of } \\
\text { progress during their } \\
\text { professional lives }\end{array}$ & 1.70 & 0.571 & 2.28 & 1.127 & 2.04 & 0.054 \\
\hline $\begin{array}{l}\text { Research is really } \\
\text { important for the } \\
\text { advancement of } \\
\text { profession and for } \\
\text { functioning the entire } \\
\text { health system }\end{array}$ & 1.86 & 0.631 & 1.94 & 0.998 & 0.361 & 0.720 \\
\hline ad.f. $=55$ & & & & & & \\
\hline
\end{tabular}

There was not statistically significant difference between 1st year and 4th year students $\mathrm{p}>0.05$ in their opinions and attitudes about professional and scientific advancement of nurses.

Majority of health care students (1st year $=77,8 \%$; 4 th year $=75,7 \%$ ) showed interest for further academic progress in field of nursing after graduating health care study program. Students had their opinion about nursing profession (Table 3).

Table 3. Students' attitudes and opinions about nursing as a profession

\begin{tabular}{|c|c|c|c|c|c|c|}
\hline \multirow[b]{3}{*}{$\begin{array}{l}\text { Nursing is really } \\
\text { complicated and } \\
\text { demanding job }\end{array}$} & \multicolumn{2}{|c|}{ 1st year } & \multicolumn{2}{|c|}{ 4th year } & \multicolumn{2}{|c|}{ t-testa } \\
\hline & $\bar{x}$ & SD & $\bar{x}$ & SD & $\mathrm{t}$ & $\mathrm{p}$ \\
\hline & 1.27 & 0.45 & 1.11 & 0.32 & 1.50 & 0.14 \\
\hline $\begin{array}{l}\text { In health institutions } \\
\text { nursing functions in } \\
\text { the frame of relative } \\
\text { autonomy }\end{array}$ & 3.19 & 0.78 & 3.61 & 0.85 & 1.83 & 0.07 \\
\hline $\begin{array}{l}\text { Other members of } \\
\text { the team appreciate } \\
\text { nurses as experts }\end{array}$ & 3.43 & 1.04 & 3.67 & 0.97 & 0.80 & 0.43 \\
\hline $\begin{array}{l}\text { Nursing is exclusively } \\
\text { female profession }\end{array}$ & 4.14 & 0.86 & 3.83 & 0.71 & 1.30 & 0.20 \\
\hline $\begin{array}{l}\text { Media show the work } \\
\text { of nurses adequately }\end{array}$ & 3.46 & 0.90 & 3.56 & 0.78 & 0.39 & 0.70 \\
\hline $\begin{array}{l}\text { Nursing is appreciate } \\
\text { profession in Rebulic } \\
\text { of Srpska }\end{array}$ & 3.97 & 0.96 & 4.17 & 0.79 & 0.74 & 0.46 \\
\hline $\begin{array}{l}\text { Nurses should } \\
\text { participate in creating } \\
\text { health policy }\end{array}$ & 1.08 & 0.28 & 1.00 & 0.00 & 1.78 & 0.08 \\
\hline ad.f. $=55$ & & & & & & \\
\hline
\end{tabular}

There was not statistically significant difference between 1st year and 4th year students in their opinions and attitudes about nursing as a profession $(\mathrm{p}<0,05)$.

92.7\% of respondents consider that nurses or medical technicians are not adequately paid for the work they do.

In relation to the degree of interest for performing tasks most of the students chose to work in their profession as Bachelors of Health care and Nursing (1st year 40.4\%; 4th year 55.6\%), and for managerial job as head nurse (1st year $43,2 \%$; 4 th year $27.8 \%)$. There is great interest among students for teaching (1st year 18.9\%; 4 th year 27.8\%). There is not statistically significant difference between 1st year and 4 th year students concerning abandonment of nursing profession $(\mathrm{t}=1.28, \mathrm{p}=0.21)$. 
Most of the students chose to work abroad after graduating (1st year $76.6 \%$; 4 th year $77.8 \%$ ).

\section{Discussion}

Results of our research show that there is statistically significant difference between the ages of respondents $(\mathrm{p}<0.001)$. Majority of the tested 1st year students was at the age of 18 to 22, and majority of the 4th year students was at the age of 23 to 27. Distribution by gender of both generation points that there is significantly larger number of females. According to the data from the literature, females, in their middle ages, are more likely to choose nursing as a profession compared to men. Age difference significantly affects the motives and expectations of the students. Students, who are a bit older than the average, accepts new knowledge, and younger students contribute significantly to constant scientifically and professional progress in nursing. 7 In conducted research $(96,4 \%)$ of the students are unemployed. Others researches show that employment among students is significantly higher, and that their employment has little affect on their academic achievements. ${ }^{7,9,12}$

In our study half of the studets finished medical high school, whereas the study coducted in Bahrian (2012) shows that all students who enroll the studies have degree from medical high school. ${ }^{8}$

As for the criteria that motivate studets to choose nusring study, the dominant factor is said to be material component with possibility of fiding better job. There is also great willingness to help others. Data from the literature point similar motives for enrolling nursig study. ${ }^{7-10}$ In coutries around the world there is obvious deficit of nurses which enables people in this profession to find jobs fast and more easiely and also to have long time position.$^{11}$

Longitudinal research on the evaluation of nursing curriculum at Southern Cross University in Australia points that average grade was from 3.89 , in 2006 , to 4.00 , in 2008. ${ }^{12}$ Health care students evaluated curriculum and the quality of the practical work of teaching with 3,22 \pm 0,76 . For students to give higher evaluation of curriculum, it is neccessary to work to improve curriculum which would ultimately mean better education.

Both generations of students showed great interest for further academic progress in graduate health care studies. Data from the literature point similar results. ${ }^{7,8,13}$ Further academic progress contributes to professional and scientific improvement of nurses, and it also justifies the introduction of doctoral studies for nurses in our country. Majority of the students is ready to work as nurses after graduating without thinking of leaving nursing profession. Other researches show that there are different interests among students, but majority of them decides to stay in nursing profession. ${ }^{13-15}$

The importance and role of Bachelors of Health care and Nursing are still not enough recognized.

In order to promote health care as better as possible, it is necessary to make development health care strategy and involve nurses who have positive attitudes. Health care students have positive attitude about nursing, but at the same time they think that nursing is not appreciated profession in Republic of Srpska. These results indicate the results of similar studies. , $^{94-16}$

Health care students mostely dissagree that nursing is female profession, although there is dominance of females. Similar results are obtained in other researches where students defended the idea that gender should not be the key factor in the choice of profession. ${ }^{18,19}$

However, the study of Karabacak and associates (2012) found that male health care students are differently perceived by the public in relation to female students, because it had long been believed that nursing was exclusively female profession. ${ }^{20}$

In a survey conducted among doctors and nurses both groups of respondents estimated to have a low level of personal involvement in their organizations and insufficient participation in work teams, and nurses considered themselves to be inferior to physicians. ${ }^{21}$ Research conducted in Italy suggests that nurses throughout history did not have rights similar to other health care professionals..$^{22}$ The results of our study show that nursing in health care institutions does not operate within the framework of autonomy and that nurses should be more involved in policymaking. This result could explain the numerous problems in nursing: the low status of health care, poor financial status of nurses, unregulated issue of education and vocation of nurses, as well as poor motivation for improving the quality of health care.

When we asked:"Where would you like to work after graduating?", majority of students chose to go and work abroad (1st year $67,6 \%$; 4 th year $77,8 \%$ ), while a smaller number of students expressed a desire to remain in their country. Similar results were obtained in studies conducted in different countries. ${ }^{7,13-16}$ So far, establishing a European labor market for occupations in the health sector has not led to extensive migration among the EU member states. However, in the coming years the mobility of health professionals is expected to increase. The motives of health professionals to leave their country can be attributed to low wages, poor working conditions, undefined competence, lack of health resources and limited opportunities for career advancement. ${ }^{23}$ 


\section{Conclusions}

The results of this research showed that the motivations of enrollment of health care in our country and other countries do not differ significantly. The dominant factor is said to be material component with possibility of fiding better job. There is also great willingness to help others.

Students generally expressed a positive attitude about nursing as a profession and evaluated study program with a relatively high grade, while 1st year and 4th year students' opinions were divided in terms of available nursing literature.

The results show that it is necessary to try to improve curriculum in accordance with the needs of the labor market and European guidelines for study program to have better quality and to draw attention of younger and older students.

This research shows that the implementation of longitudinal studies with 1st year students at the end of their schooling, with the same measuring instrument, would give a more complete picture of the health care study.

\section{References}

1. Institute of Medicine, The future of nursing: Leading change, advancing health. Washington, DC: National Academies Press. Report Recommendations 2010. (4-5).

2. Strategic directions for strengthening nursing and midwifery services 2011-2015“ (3), WHO 2010. (5-6).

3. Munich Declaration: Nurses and Midwives: a Force for Health (Minhenska deklaracija: Medicinske sestre i babice: Snaga za zdravstvo), Kopenhagen, Regionalna kancelarija SZO za Evropu, 2000.

4. Büscher A., Sivertsen B., White J., Nurses and Midwives: A force for health. Survey on the situation of nursing and midwifery in the Member States of the European Region of the World Health Organization 2009.(40-44).

5. Linda HP, Terrill E., White P., Rico J. Integrative Review of Graduate Entry Programs in Nursing, Journal of Nursing Education, January 2012; 51(1): 29-37.

6. McMillan DE, Bell S., Benson EE, Mandzuk LL, Matias DM, McIvor MJ, Robertson JE and Wilkins KL, From Anxiety to Enthusiasm: Facilitating Graduate Nursing Students' Knowledge Development in Science and Theory; Journal of Nursing Education; February 2007; 46 (2):88-91

7. Mrnjec V: Motivi i očekivanja studenata Sveučilišnog diplomskog studija sestrinstva nakon završetka studija. SG/NJ 2014; 19:95102.
8. Eman T, Seamus C, Edgar A: A triangulation study: Bahraini nursing students' perceptions of nursing as a career. Journal of Nursing Education and Practice, August 2012; 2 (3):81-92.

9. Sand-Jecklin K. E. and Schaffer A. J: Nursing Students' Perceptions of Their Chosen Profession. Nursing Education Perspectives: May 2006; 27 (3): 130-135.

10. Miligi E, Selim A: Saudi Nursing Students' Attitudes towards the Nursing Profession. European Journal of Business and Management. 2014; 6 (29): 197-208.

11. Gutierrez, San. R. S., Maranon A. A., Poch B. E., Prat, V. O. Factors influencing the choice of nursing studies [Spanish]. Enfermeria Clinica. July- Aug 2010; (40), 36-42.

12. van de Mortel TF, Bird JL: Continuous curriculum review in a bachelor of nursing program: preventing curriculum drift and improving quality. J Nurs Educ. 2010 Oct; 49(10):592

13. Al Jarrah A. T. I: Associate nursing students, perceptions toward nursing profession in Jordan. European Scientific Journal February 2013; 9(6): 147-166.

14. Čukljek S, Karačić J, Ilić B. (2011.) Stavovi studenata 3. godine studija sestrinstva o sestrinstvu u Hrvatskoj danas. Opatija: Hrvatsko sestrinstvo ususret Europskoj uniji; str. 169-176.

15. Patidar A. B, Kaur J, Sharma K. S, Sharma N: Future nurses' perception towards profession and carrier plans: A cross sectional survey in state Punjab. Nursing and Midwifery Research Journal, October 2011; 7(4): 175-185.

16. Mahran S. M. A, Nagshabandi A. E: Impact of Perceived Public Image on Turnover Intention of Female Students from Joining To Nursing Profession At King Abdul-Aziz University, Kingdom Saudi Arabia. Nursing and Health Sciences 11/2012; 1:0-0.

17. Shukri RK, Bakkar BS, El-Damen MA, Ahmed SM: Attitudes of Students at Sultan Qaboos University towards the Nursing Profession. Sultan Qaboos Univ Med J. 2013 Nov;13(4):539-44.

18. Koushali A. N, Hajiamini Z, Ebadi A: Comparison of nursing students' and clinical nurses' attitude toward the nursing profession. Iran J Nurs Midwifery Res. 2012 Jul-Aug; 17(5): 375-380

19. Toren O, Zelker R, Porat N: Preferences of Israeli nursing students in choosing their future workplace. Journal of Nursing Management. 2012; 20: 45-55.

20. Karabacak Ü, Uslusoy E, Alpar S,E, Bahçecik N. Image of nursing held by nursing students according to gender: A qualitative study. International Journal of Nursing Practice. 2012; 18: 537-544.

21. Skela Savič B, Pagon M: Relationship Between Nurses and Physicians in Terms of Organizational Culture: Who Is Responsible for Subordination of Nurses? Croat Med J. Jun 2008; 49(3): 334343 .

22. Kangasniemi M, Stievano A, Pietilä AM: Nurses' perceptions of their professional rights. Nurs Ethics. 2013 Jun;20(4):459-69.

23. Gerlinger T, Schmucker R: Transnational migration of health professionals in the European Union. Cad Saude Publica. 2007;23 Suppl 2:S184-92. 


\section{Stavovi i mišljenja studenata zdravstvene njege Medicinskog fakulteta u Banjoj Luci o studijskom programu i sestrinstvu kao profesiji}

\section{SAŽETAK}

Uvod: Stepen kvaliteta obrazovanja diplomiranih medicinara zdravstvene njege zavisi od kvaliteta nastavnog plana i programa. Saznanja o onom šta motiviše studente za upis na studij zdravstvene njege i razvoj stručne i akademske karijere od izuzetnog su značaja, kako za obrazovanje, tako i za praksu.

Cilj rada: Ispitati da li postoji razlika u stavovima i mišljenjima studenata I i IV godine o studijskom programu zdravstvene njege, sestrinstvu kao profesiji, motivima upisa studenata, kao i njihovim očekivanjima u vezi sa mogućnostima ličnog, stručnog i naučnog napredovanja nakon završenog studija.

Ispitanici i metode: Uzorak su činila 55 studenta zdravstvene njege Medicinskog fakulteta Univerziteta u Banjoj Luci (I godina 37 i IV godina 18 studenata). Istraživanje je sprovedeno upotrebom anonimnog, originalnog anketnog upitnika koji je konstruisan za potrebe ovog istraživanja. Za obradu podataka korišten je SPSS (Statistical Product and Service Solutions) verzija 20.Windows, operativni program za analizu podataka.

Rezultati: Sprovedeno istraživanje ukazuje da su materijalna komponenta, uz mogućnost nalaženja boljeg posla i spremnost da se brinu o drugim ljudima, glavni kriteriji koji motivišu studente da izaberu studij sestrinstva. Studenti obe generacije zdravstvene njege ocijenili su studijski program sa ocjenom $3,22 \pm 0,76$, a postojala je statistički značajna razlika $(p<0.001)$ u pogledu dostupnosti literature. Obe generacije studenata imaju pozitivne stavove o sestrinstvu kao profesiji. Većina studenata (I godina = 77,8\%; IV godina $=75,7 \%$ ) pokazala je interes za dalje akademsko napredovanje nakon završetka studija zdravstvene njege. Za odlazak u inostranstvo opredijelio se veliki broj studenata (I godina 67,6\%; IV godina 77,8\%), dok je manji broj njih izrazio želju da ostane u svojoj zemlji nakon završenog studija.

Zaključak: Motivi upisa na studij zdravstvene njege kod nas i u drugim zemljama bitno se ne razlikuju, a najčešće navođeni razlozi su mogućnost boljeg zaposlenja i želja za pomoć drugima. Akademski program studija zdravstvene njege morao bi biti izuzetno kvalitetan, ali i dovoljno atraktivan kako bi privukao studente mlađe i starije životne dobi.

Ključne riječi: studij sestrinstva, stavovi studenata, motivi upisa, očekivanja. 